Vol. 38(1), pp. 97-115, June 2019

ISSN 1821-536X (print)

ISSN 2619-8789 (electronic)
Tanzania Journal of Engineering and Technology

Copyright (C) 2019 College of Engineering and

Technology, University of Dar es Salaam

Full Length Research Paper

\title{
Material Flow Analysis as a Decision Supporting tool for Faecal Sludge Resource Recovery: Mathematical formulation and quantification
}

\author{
Isabela T. Mkude ${ }^{1 *}$, Tolly Mbwette ${ }^{1}$, Richard Kimwaga ${ }^{1}$, Sara Gabrielsson ${ }^{2}$ \\ ${ }^{1}$ Department of Water Resources Engineering, College of Engineering and Technology, \\ University of Dar es Salaam, Tanzania \\ ${ }^{2}$ Lund University Centre for Sustainability Studies (LUCSUS), Lund University, Sweden \\ *Corresponding author: isabela.thomas@yahoo.com
}

\begin{abstract}
In this work, a conceptual framework for faecal sludge (FS) management and resource recovery in Dar es Salaam city was developed. Material Flow Analysis (MFA) approach was used to assess and quantify the current materials and nutrients to support on decisions for nutrient recovery and minimize environmental pollution in three unplanned settlements of Manzese, Keko and Kipawa in Dar es Salaam city. Nitrogen and Phosphorus were chosen as indicators for the evaluation of the process. The results showed that about $75 \%$ of the Dar es Salaam city population relies on pit latrines and 15\% connected to septic tanks, translating to a large amount of faecal sludge being contained onsite. The situational analysis study on faecal sludge management (FSM) showed that the collection, treatment and proper disposal of FS are the major challenges that pose risks to public health. Currently, 57\% of faecal sludge generated in Dar es Salaam is disposed to the environment inappropriately. Onsite Sanitation Systems in all study areas are the main polluters, discharging large quantity of nutrients to the environment. About $37.7 \%$ of faecal sludge is with large amount of nutrients emptied from onsite sanitation systems discharged to the environment and through seepage to the groundwater.
\end{abstract}

Keywords: Faecal sludge; Material flow analysis; Resource recovery; unplanned settlements.

\section{INTRODUCTION}

Faecal sludge (FS) is an organic material that can be reused as organic fertilizer, source of energy or source of protein for animal feeds (Diener et al., 2014), which can contribute to solving soil degradation, food insecurity, environmental pollution and lack of energy access challenges (Munamati et al., 2016). Nitrogen and Phosphorus are nutrients in faecal sludge, which are estimated to be $8.2 \mathrm{~g} / \mathrm{L}$ and 1.1 $\mathrm{g} / \mathrm{L}$, respectively of dry faecal sludge (Andriani et al., 2015). About 50-90\% of organic matter in FS possesses the recovery opportunities.

Chemical fertilizer is one among musthave commodity for most African farmers in increasing soil fertility and crop production, but it is expensive which calls for a substitute cheaper material. On the other hand, access to urban domestic energy sources is a challenge resulting to dependency on solid fuels as a source of energy for cooking across urban areas in Africa followed by gas and liquid fuels (Drechsel et al., 2004). The need for 
resources recovery from faecal sludge is an opportunity that can integrate new ideas and technology with existing sanitation collection and treatment systems. Through thermal decomposition, FS sludge material can successfully be processed for energy recovery because of its rich carbon content (Kwapinski et al., 2010) to substitute with the use of firewood, charcoal or other solid fuels (Gold et al., 2018; Liu et al., 2014) and contributing in saving money, decrease local deforestation rates and provide income generating opportunity (Nyer, 2012).

To assess resource consumption and environmental impacts of resources from sanitation systems, Material Flow Analysis (MFA) method that uses quantitative procedures to systematically assess matter and substances within a system can be used (Do-thu et al., 2011; Strauss and Montangero, 2002). This tool has been widely applied in the field of environmental sanitation in urban areas and in industrial processes of developing countries since the 1990s (Montangero and Belevi, 2007; Do-thu et al., 2011). MFA approach assists the decision making by estimating the total quantities of reuse products to be produced.

About $90 \%$ of Dar es Salaam population relies on onsite sanitation systems while only $43 \%$ of generated faecal sludge is collected and safely treated in Waste Stabilization Ponds (WSPs) (Brandes et $a l ., 2015)$. At the endpoints of WSP, recovery of treated liquid effluents is informally utilized in urban agricultural activities, growing leafy vegetables like Amaranth, pumpkin leaves and okra along water sources including Msimbazi, Mzinga, Kizinga and Ng'ombe rivers, inplots and on backyard gardens (Dongus et al., 2009; Leonard et al., 2012). However, the quality of water is still questionable because several researchers have reported the presence of pathogenic organisms in these vegetables, which might pose potential human health risks (Kayombo and Mayo, 2018; Malale and Munishi, 2018).

The large amount of piled up treated semisolid part of faecal sludge from WSPs is another management challenge that municipals are facing (Gold et al., 2014). This can be taken as recovery opportunity to produce soil conditioning material or solid fuel for cooking instead of disposing it to the environment (Atwijukye et al., 2018; Niwagaba et al., 2009; Niwagaba et al., 2014). The objective of this study was to quantify materials flow to the households and nutrients (nitrogen and phosphorus) through the sanitation service chain in order to contribute to the decision making on the process for pollution mitigating measures. The emphasis in this study was the concept of resource reuse efficiency in sanitation in unplanned settlements of Dar es Salaam city.

\section{MATERIALS AND METHODS}

\section{Description of Study Areas}

The targeted study areas were three unplanned settlements in Dar es Salaam city, namely Manzese, Keko and Kipawa, located in Ubungo, Temeke and Ilala Municipalities, respectively (Figure 1). The study area covers an area of $19 \mathrm{~km}^{2}$ with an estimated total population of 224,140 (NBS, 2017). Three wards represent typical middle to low-income communities living in urban unplanned settlements of Dar es Salaam. These areas are densely populated with both residential and commercial buildings. A large portion of grey water is directed to either onsite sanitation facilities or disposed of to the environment through open channels or pipes (Kasala, 2016). 


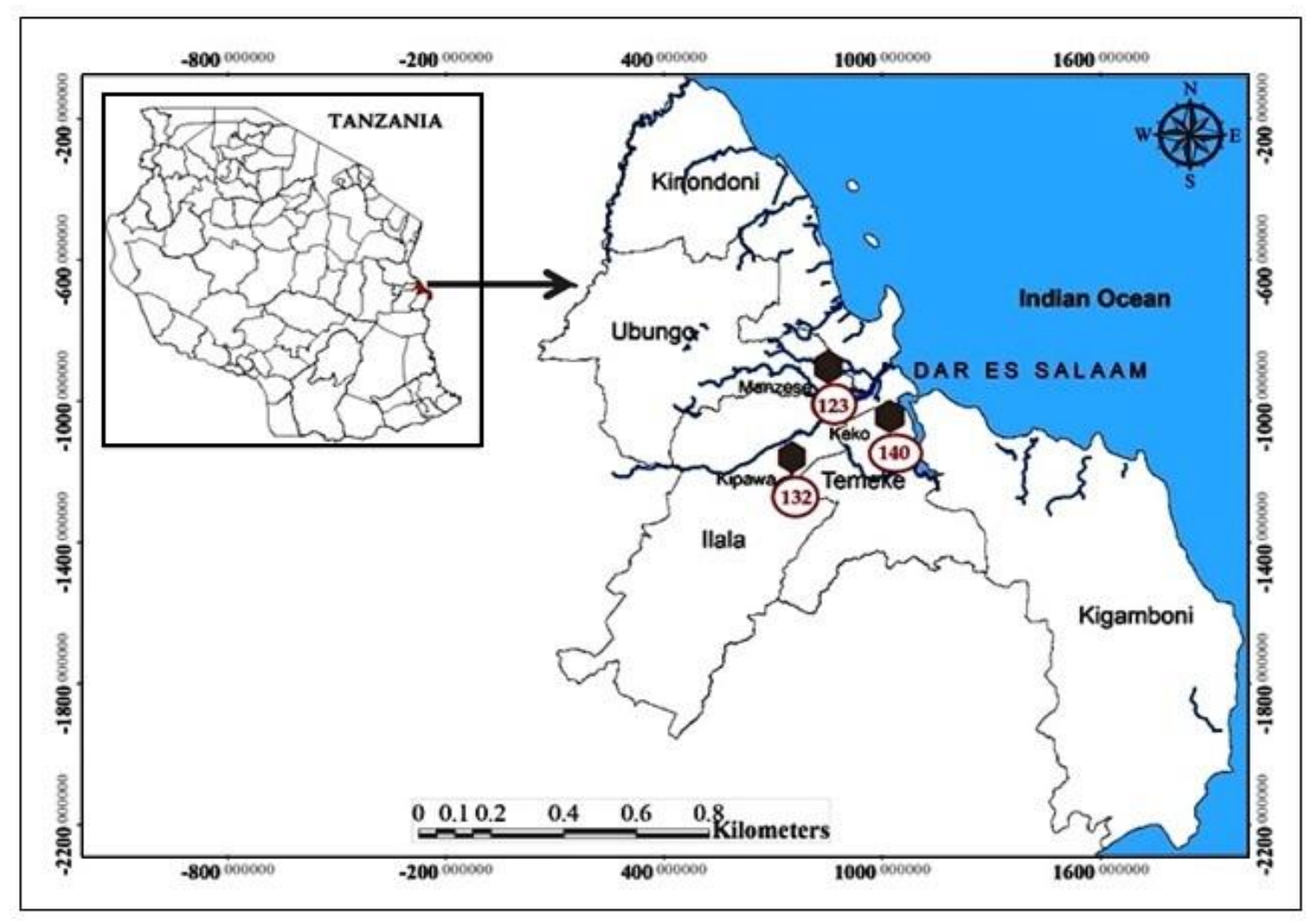

Figure 1: Location of study areas and sampling points for the household survey.

\section{Data Collection and Analysis}

The mixed-method of data collection was deployed for both qualitative and quantitative data collected between September 2017 and November 2018. Key informants' interviews with sanitation stakeholders were conducted to assess the City-wise practices on faecal sludge management and plans along the sanitation service chain. The questionnaires survey was conducted by using mobile phone application known as Epicollect5. The sample size for the questionnaire survey was obtained using the equation (1).

$\mathbf{n}=\frac{\mathrm{N}}{1+\mathrm{N}(\alpha)^{2}}$

Where $\mathrm{n}=$ sample size, $\mathrm{N}=$ total number of houses/population/units to be studied; $70 \%$ of total population (Brandes et al, 2015) and $\alpha=$ the margin of error or desired level of precision, at confidence level of $95 \%$ is $\pm 5 \%$ (de Langen, 2007). A total number of 400 respondents (n) was obtained, which was proportionally distributed in three study areas according to the present population of the area. The households' samples were randomly selected.

The administered questionnaires contained five parts which seek primary information from study population including; (i) Socioeconomic characteristics, (ii) Sanitation and water use, (iii) Community engagement to sanitation and FSM activities (iv) Community health and (v) Sustainable sanitation and resource recovery. Focus group discussions were conducted to gather information on the insights from the community about knowledge, challenges, and opportunities available on resource recovery plans and preferences on faecal-based products. Secondary information on nitrogen and phosphorus concentrations estimations and 
calculations in different materials (food, water and faecal sludge) used from published documents as well as institutional and national reports available online and in the offices were also identified and used. Assumptions made and relevant information adopted was stated in respective areas when they were used.

After collection, data were extracted and saved as Microsoft Excel 2010 spread sheet file. The file was coded and manually double-checked to eliminate the risk of any mistakes. The Statistical Package for Social Science (SPSS 21) was used to calculate the frequencies and relative frequency of responses.

\section{Material Flow Analysis (MFA) System}

MFA system under investigation defined the spatial boundary of three selected administrative wards and one year as a temporal boundary. The mass flows of materials such as water and food and substances such as nitrogen and phosphorus were calculated through a defined system. All calculations for quantification were performed by Microsoft Excel program Version 2010 following different mathematical formulae while mass balances and pictorial representations were performed by Software for Substance Flow Analysis (STAN) version 2.1 (Cencic and Rechberger, 2008). Processes under MFA are represented by boxes while flows are represented by arrows. No stock amount from the previous year of materials and substances were considered in the calculations. To quantify stocks and flows, each particular material was identified as a whole or with ratios allocated to different processes (Allesch and Brunner, 2015).

The scenario represents current situation system consists of 5 processes with 13 flows (Figure 2). However, surface water, ground water and atmosphere processes were not considered because they are beyond the system boundaries and scope of this study. The impact of environmental sanitation systems on the nitrogen and phosphorus load was analyzed from the rest of the processes.

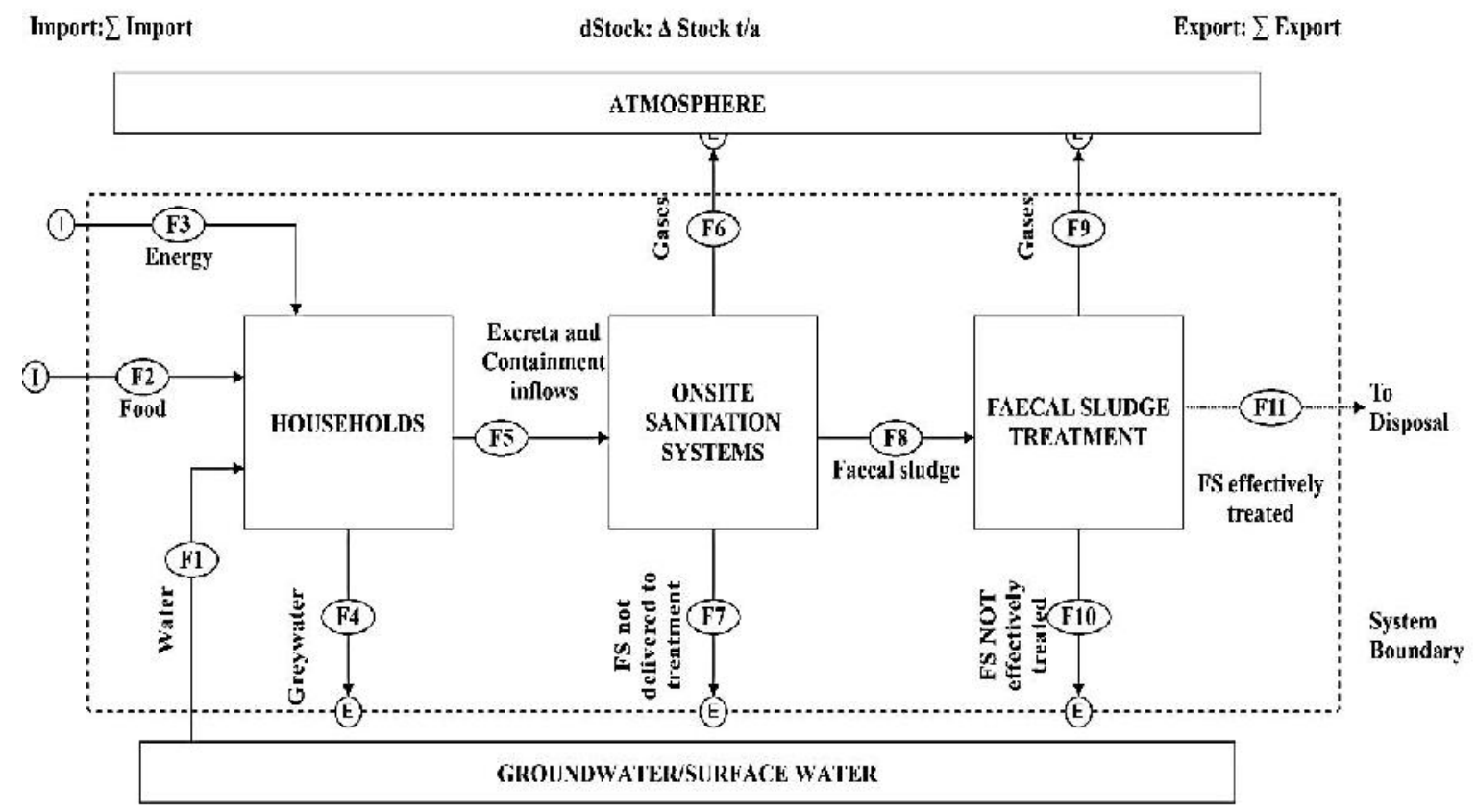

Figure 2: Material flow analyses for current situation scenario

\section{Mathematical Formulation}


Material Flow Analysis follows the law of conservation of mass. All inputs, stocks and outputs data of a process were obtained from different sources and calculated using mathematical formulae under each process. The uncertainty analysis was performed to propagate uncertainties for MFA inputs so as to determine distribution of outputs depending on the source of data to be used. When variable obtained contains arithmetic mean value $(\overline{\overline{\mathrm{X}}})$ and standard deviation (SD) calculated from data set available, the uncertainty $\left(U_{r}\right)$ calculated using Gauss error traditional approach by dividing (SD) with ( $\overline{\mathrm{X}}$ ) times $100 \%$. If no uncertainty defined for a particular parameter and only lower and upper bounds available, a general uncertainty of $10 \%$ was assumed as suggested by Meinzinger (2010). All data calculated included the uncertainty value in form of $\overline{\mathrm{X}} \pm \mathrm{U}_{\mathrm{r}}$.

\section{Households}

Potable water (F1), food supply (F2) and energy sources for kitchen use needed in the house (F3) were the inputs to households, while greywater (F4) and excreta with containment inflows (F5) were the outputs. The average water consumption per capita per day was obtained from the household questionnaire survey as volume (L/d) converted to mass unit considering $1000 \mathrm{~kg} / \mathrm{m}^{3}$ as a density of water (Cencic and Rechberger, 2008).

Food amount was calculated by summing up annual per capita food items supplied under the current Tanzania Food Balance sheet estimated by the Food and Agriculture Organization (FAO, 2013). The energy sources considered at household level was wood charcoal based on dominant energy source requirement for kitchen purposes obtained from a questionnaire survey. The value of wood charcoal was extrapolated from the amount reported by Msuya et al. (2011) using the current population and calorific values the amount of energy source, which was obtained from equation (2) in accordance with Meinzinger (2010).

$$
C_{c}=\frac{E_{C}}{C_{H V}}
$$

where $\mathrm{Ec}=$ Current energy demand from wood charcoal $(\mathrm{kWh} / \mathrm{cap} / \mathrm{yr}), \mathrm{C}_{\mathrm{c}}=$ Current consumption of charcoal (t/cap/yr) and $\mathrm{C}_{\mathrm{HV}}=$ heating value of charcoal $(\mathrm{kWh} / \mathrm{kg})$.

Greywater generation from dishwashing and laundry activities was estimated on assumption that $65 \%$ to $75 \%$ of domestic water consumption was converted to greywater (Chaggu, 2004; Diener et al., 2014; Do-thu et al., 2011; Katukiza, 2013). Adopting $75 \%$ of water consumption, the total greywater generated in this study was calculated. The amount of excreta production was calculated from equation (3) using secondary data of similar locality of developing countries (Marwa, 2017; Schoebitz et al., 2014).

$$
\mathrm{E}_{\mathrm{p}}=\mathrm{U}_{\mathrm{p}}+\mathrm{F}_{\mathrm{p}}
$$

where $\mathrm{E}_{\mathrm{p}}=$ excreta produced $(\mathrm{kg} / \mathrm{cap} / \mathrm{d})$; $\mathrm{U}_{\mathrm{p}}=$ urine produced $(\mathrm{kg} / \mathrm{cap} / \mathrm{d})$ and $\mathrm{F}_{\mathrm{p}}=$ faeces produced $(\mathrm{kg} / \mathrm{cap} / \mathrm{d})$.

Containment inflow is the amount of black water that goes out of the toilet together with excreta to sanitation systems. This includes water used for anal cleansing and bathing, which is discharged to onsite sanitation systems. Nitrogen and phosphorus are the major nutrients proposed for assessment. Nitrogen enters household mainly through food while phosphorus enters through food and other sources like detergents used for cleaning and laundry activities. The general nitrogen and phosphorus mass balance equations in the process are expressed by equations (4) and (5), which considers all input and output flows. 
$A_{\mathrm{NF} 1}+\mathrm{A}_{\mathrm{NF} 2}+\mathrm{A}_{\mathrm{NF} 3}=\mathrm{A}_{\mathrm{NF} 4}+\mathrm{A}_{\mathrm{NF} 5}$

$A_{\mathrm{PF} 1}+\mathrm{A}_{\mathrm{PF} 2}+\mathrm{A}_{\mathrm{PF} 3}=\mathrm{A}_{\mathrm{PF} 4}+\mathrm{A}_{\mathrm{PF} 5}$

where $A_{N}$ and $A_{p}$ are the amounts of Nitrogen and Phosphorus flowing through flows (F1), (F2), (F3), (F4) and (F5), respectively.

\section{Onsite sanitation systems}

Excreta and containment inflows (F5) are the only inputs to onsite sanitation systems (OSSs). Rainwater inflows and solid waste inputs were neglected in calculations for this case. The outputs from the onsite sanitation system process are gases emitted (F6), total faecal sludge emptied and delivered to treatment plants (F8) and fraction of faecal sludge which was not delivered to treatment plants (F10).

The total faecal sludge generated is a function of excreta produced and containment inflows, which is the amount of blackwater disposed to the onsite sanitation systems (Marwa, 2017; Schoebitz et al., 2014). A summarised findings from the survey on fraction distribution of generated faecal sludge in study areas is presented in Table 1.

Table 1: Fraction distribution of generated faecal sludge

\begin{tabular}{|c|c|c|c|c|c|}
\hline \multicolumn{2}{|l|}{ Study areas } & Keko & Kipawa & Manzese & Reference \\
\hline \multicolumn{2}{|l|}{ Population } & 79,453 & 74,180 & 70,507 & NBS (2017) \\
\hline \multicolumn{2}{|c|}{ Fraction of pit latrines available (\%) } & $27.1 \%$ & $35.9 \%$ & $61.8 \%$ & This study \\
\hline \multicolumn{2}{|c|}{ Fraction of septic tanks available $(\%)$} & $72.1 \%$ & $63.4 \%$ & $38.2 \%$ & This study \\
\hline \multicolumn{2}{|l|}{ FS generated (kg/cap/d) } & $9.65 \pm 1.34$ & $11.38 \pm 1.85$ & $8.65 \pm 1.59$ & This study \\
\hline \multirow[b]{2}{*}{ FS emptied } & $\begin{array}{l}\% \text { of } \\
\text { generated FS }\end{array}$ & $43 \%$ & $39 \%$ & $76 \%$ & This study \\
\hline & $(\mathrm{kg} / \mathrm{cap} / \mathrm{d})$ & $4.15 \pm 0.58$ & $4.44 \pm 0.72$ & $6.57 \pm 1.21$ & This study \\
\hline $\begin{array}{l}\text { FS emptied-delivered } \\
\text { to treatment points } \\
(\mathrm{kg} / \mathrm{cap} / \mathrm{d})\end{array}$ & $\begin{array}{l}27 \% \text { of FS } \\
\text { Emptied }\end{array}$ & $1.12 \pm 0.16$ & $1.19 \pm 0.19$ & $1.77 \pm 0.33$ & $\begin{array}{l}\text { Brandes et al. } \\
(2015)\end{array}$ \\
\hline $\begin{array}{l}\text { FS emptied- NOT } \\
\text { delivered to treatment } \\
\text { points }(\mathrm{kg} / \mathrm{cap} / \mathrm{d})\end{array}$ & $\begin{array}{l}73 \% \text { of FS } \\
\text { Emptied }\end{array}$ & $3.03 \pm 0.42$ & $3.24 \pm 0.53$ & $4.79 \pm 0.88$ & $\begin{array}{l}\text { Brandes et al. } \\
(2015) ; \text { Jenkins et } \\
\text { al. }(2015) \text {. }\end{array}$ \\
\hline $\begin{array}{l}\text { FS not emptied- not } \\
\text { contained -seepage \& } \\
\text { illegal disposal } \\
(\mathrm{kg} / \mathrm{cap} / \mathrm{d})\end{array}$ & $\begin{array}{l}11.2 \% \text { of FS } \\
\text { generated }\end{array}$ & $1.08 \pm 0.15$ & $1.27 \pm 0.21$ & $0.97 \pm 0.18$ & $\begin{array}{l}\text { Brandes et al. } \\
(2015)\end{array}$ \\
\hline $\begin{array}{l}\text { FS not Emptied- } \\
\text { Stock (kg/cap/d) }\end{array}$ & $\begin{array}{l}37.2 \% \text { of FS } \\
\text { generated }\end{array}$ & $3.57 \pm 0.50$ & $4.21 \pm 0.68$ & $3.20 \pm 0.59$ & $\begin{array}{l}\text { Brandes et al. } \\
(2015) \text {; Jenkins et } \\
\text { al. }(2015) .\end{array}$ \\
\hline
\end{tabular}

Methane $\left(\mathrm{CH}_{4}\right)$ gas can be emitted from onsite anaerobic sanitation systems when methanogens become active at a temperature above $15^{\circ} \mathrm{C}$ (Orner and Mihelcic, 2018). The estimation of methane emission from latrines (traditional and VIPs) is a function of the daily mass of biochemical oxygen demand (BOD) in the influent, organic matter removal efficiency and other conversion factors.
IPCC Guidelines for National Greenhouse Gas presents simplified general equations to estimate $\mathrm{CH}_{4}$ emissions from domestic wastewater (IPCC, 2006) in accordance with equation (6).

$$
{ }_{R}^{\mathrm{CH}_{4} \text { emission }}=\left(B O D_{T} \times B_{\odot} \times M C F\right)-
$$


where $\mathrm{CH}_{4}$ emissions $=\mathrm{CH}_{4}$ emissions in inventory year in $\mathrm{kg} \mathrm{CH} / \mathrm{yr}, \mathrm{BOD}_{\mathrm{T}}=$ Total organics in wastewater in inventory year in $\mathrm{kg} \mathrm{BOD} / \mathrm{yr}, \mathrm{R}=$ amount of $\mathrm{CH}_{4}$ recovered/recycled in inventory year in $\mathrm{kg}$ $\mathrm{CH}_{4} / \mathrm{yr}$. No recycling was performed, hence $\mathrm{R}$ was assumed to be zero, Bo = maximum $\mathrm{CH}_{4}$ producing capacity in $\mathrm{kg}$ $\mathrm{CH}_{4} / \mathrm{kg} \mathrm{BOD}$; given $0.6 \mathrm{~kg} \mathrm{CH} / \mathrm{kg}$ BOD as default, $\mathrm{MCF}=$ methane correction factor (fraction), which was assumed to be 0.5 for septic tanks (half of BOD settles in an anaerobic tank), and 0.7 for pit latrine (wet climate/flush water use, higher groundwater table).

To balance Nitrogen and Phosphorus amounts in onsite sanitation systems process (OSSs), equations (7) and (8) were used to consider all input and output flow.

$$
\begin{aligned}
& A_{\mathrm{NF} 5}=A_{\mathrm{NF} 6}+A_{\mathrm{NF} 7}+A_{\mathrm{NFg}} \ldots \ldots \\
& A_{\mathrm{PF} 5}=A_{\mathrm{PF} 6}+A_{\mathrm{PF} 7}+A_{\mathrm{PF} 8} \ldots \ldots
\end{aligned}
$$

where the $A_{N}$ and $A_{P}$ are the amount of Nitrogen and Phosphorus flowing through flows (F5), (F6), (F7) and (F8), respectively.

Different conditions occur inside specific onsite sanitation systems. In the septic tank, settling and partial decomposition of organic matter occurs while the accumulation of solids and infiltration of liquid occurs in pit latrines (Montangero et al., 2007). Transfer coefficients for each nutrient $(k N)$ and $(k P)$ should be considered depending on physical and biochemical processes that occur in different sanitation systems. Transfer coefficients for nutrients from both septic tanks and pit latrines are partitioned into leachate and sludge. Depending on the local conditions of specific areas, different ranges exist as reported by previous studies (Montangero, 2006; Montangero and Belevi, 2007; Montangero and Belevi, 2008).

The adopted coefficients to use for Nitrogen, $k N$ and Phosphorus, $k P$ selected as 0.09 and 0.18 for septic tanks respectively. The $k N=0.18$ and $k P=0.29$ were also selected for pit latrine. Other conditions considered were fraction of septic tanks $\left(n_{S T}\right)$ and pit latrines $\left(n_{P L}\right)$ available in the area (Table 1) and faecal sludge emptying frequency factor for each facility; septic tanks $\left(F_{f r_{-} S T}\right)$ and pit latrines $\left(F_{f r_{-} p_{L}}\right)$. An average emptying frequency of once in 2 years was adopted for septic tanks $\left(F_{f r_{S T}}=2\right)$ (Montangero, 2009). Due to the high groundwater table in the study areas, emptying frequency of pit latrines was reported to be three times per year $\left(F_{f r_{-} P L}=0.33\right)$.

The mass of nutrients flowing in flow (F7) and (F8) were estimated using equations (9) and (10), respectively. The output flows from OSS process include emptied and delivered to treatment plants (F8) and that not delivered to the treatment (F7). All fractions of faecal sludge in study areas are as presented in Table 1.

$$
\begin{aligned}
& A_{N F 7} \text { and } A_{N F 8}=\left(n_{S T}\right) \cdot A_{N(f s)}^{S T}+\left(n_{P L}\right) \cdot A_{N(f s)}^{P L} \\
& A_{P F 7} \text { and } A_{P F 8}=\left(n_{S T}\right) \cdot A_{P(f s)}^{S T}+\left(n_{P L}\right) \cdot A_{P(f s)}^{P L}
\end{aligned}
$$

where the amounts of nitrogen and phosphorus in (F7) and (F8) consider both pit latrines and septic tanks fractions available.

\section{Faecal sludge treatment}

The input to faecal sludge treatment plants is a reported fraction of faecal sludge which was emptied and reached wastewater treatment plants for treatment 
(F8). The outputs include gases generated and emitted during treatment processes (F9), treated effluent to water bodies (F11) and part of effluent which was not effectively treated, but disposed to water bodies (F10). Currently, faecal sludge collected in Dar es Salaam is transported to Waste Stabilization Ponds for secondary treatment before the effluent is discharged into the rivers (Brandes et al., 2015). Two WSPs which are designated for FS treatment are located at Vingunguti and Kurasini areas, with capacity of $2000 \mathrm{~m}^{3}$ and $135 \mathrm{~m}^{3} / \mathrm{d}$ of FS, respectively (Brandes et al., 2015; EWURA, 2014).

Three primary greenhouse gases GHGs, i.e. methane $\left(\mathrm{CH}_{4}\right)$, carbon dioxide $\left(\mathrm{CO}_{2}\right)$ and nitrous oxide $\left(\mathrm{N}_{2} \mathrm{O}\right)$ (Vijayan et al., 2017) are likely to be produced from treatment systems or discharge pathways with anaerobic environments. Anaerobic ponds with depth 2-5 $\mathrm{m}$ are a critical factor in $\mathrm{CH}_{4}$ production. Methane and carbon dioxide can be calculated using equations (11) and (12).

$$
\begin{aligned}
& C O_{2}=B O D \times Q_{w w} \times E f f_{O D} \times C F_{C O_{\eta}} \times\left[\left(1-M C F_{w w} \times B G_{C H_{A}}\right)(1-\lambda)\right] \\
& C_{4}=B O D \times Q_{w w} \times E f f_{O D} \times C F_{C H_{A}} \times\left[\left(M C F_{w w} \times B G_{C H_{A}}\right)(1-\lambda)\right]
\end{aligned}
$$

where $\mathrm{CO}_{2}$ and $\mathrm{CH}_{4}$ are the air emissions $(\mathrm{kg} / \mathrm{yr}), \mathrm{BOD}$ is the daily mass of biochemical oxygen demand in the influent, which is reported to be $10 \mathrm{mg} / \mathrm{l}$ $\left(10 \mathrm{~g} / \mathrm{m}^{3}\right)$ for Vingunguti WSP (Mwakaboko et al. 2014), $\mathrm{Q}_{\mathrm{ww}}$ is wastewater influent flow rate $\left(\mathrm{m}^{3} / \mathrm{d}\right)$, which is the capacity of Vingunguti WSP $=2000 \mathrm{~m}^{3} / \mathrm{d}$ (Brandes et al., 2015; EWURA 2014). $\mathrm{Q}_{\mathrm{ww}}$ calculated from three study areas inclusively is $0.0026 \mathrm{~m}^{3} / \mathrm{cap} / \mathrm{d}$, which was converted from mass of FS (F8), EffoD is the biochemical oxygen demand removal efficiency (default assumed $80 \%$ ), $\mathrm{CF}_{\mathrm{CO} 2}$ is the conversion factor for maximum $\mathrm{CO}_{2}$ generation per unit of BOD (1.375 $\mathrm{g} \mathrm{CO}_{2}$ per $\mathrm{g}$ BOD), $\mathrm{CF}_{\mathrm{CH} 4}$ is the conversion factor for maximum $\mathrm{CH}_{4}$ generation per unit of $\mathrm{BOD}$ (0.5 $\left.\mathrm{g} \mathrm{CH}_{4} \mathrm{~g} \mathrm{BOD}^{-1}\right)$. $\mathrm{BG}_{\mathrm{CH} 4}$ is the fraction of carbon present as $\mathrm{CH}_{4}$ in generated biogas (default is 65\%),

\section{$\mathrm{N}_{2} \mathrm{O}_{\text {WWTP }}=\mathrm{N}_{\text {EFFLUENT }} \times \mathrm{EF}_{\mathrm{N}_{2} \mathrm{O}} \times \frac{44}{28}$}

$\mathrm{N}_{\text {BPFLUENT }}=\left(\mathrm{ca} \times\right.$ Protein $\left.\times \mathrm{F}_{\mathrm{NPR}} \times \mathrm{F}_{\text {NON_CON }_{-}} \times \mathrm{F}_{\mathrm{IND}_{-} \mathrm{COM}}\right)-\mathrm{N}_{\text {SLUDGE }}$

where $\mathrm{N}_{2} \mathrm{O}_{\text {wwTp }}=\mathrm{N}_{2} \mathrm{O}$ emissions in inventory year $\left(\mathrm{kg} \mathrm{N} \mathrm{N}_{2} \mathrm{O} / \mathrm{yr}\right), \mathrm{N}_{\text {EFfLUENT }}=$ total annual amount of nitrogen in the wastewater effluent $(\mathrm{kg} \mathrm{N} / \mathrm{yr}), \mathrm{EF}_{\mathrm{N}_{2} \mathrm{O}}=$ Emission factor $\left(\mathrm{gN}\right.$ emitted as $\mathrm{N}_{2} \mathrm{O}$ per $\mathrm{g}$
$\mathrm{MCF}_{\mathrm{Ww}}$ is the methane correction factor for a wastewater treatment unit usually 0.8 for anaerobic conditions and $\lambda$ is the biomass yield ( $\mathrm{g}$ C converted to biomass per g $\mathrm{C}$ consumed), also specific to each treatment unit, which is suggested to be 0.1 for anaerobic conditions.

Nitrous oxide $\left(\mathrm{N}_{2} \mathrm{O}\right)$ can be emitted directly from treatment plants or indirectly from wastewater after disposal of the effluent to the receiving body (IPCC, 2006). Amount of gases emitted for this case considered indirect emission of effluent to receiving bodies and are function of nitrogen content in the wastewater effluent, population and average annual per capita protein generation $(\mathrm{kg} / \mathrm{person} / \mathrm{yr})$. Using equations (13) and (14), the emission of nitrous oxide can be estimated.

TKN in influent). Based on limited data and assumptions on nitrification and denitrification in rivers, the default IPCC emission factor for $\mathrm{N}_{2} \mathrm{O}$ emissions from domestic wastewater nitrogen effluent is 
$0.005(0.0005-0.25) \mathrm{kg} \mathrm{N}_{2} \mathrm{O}-\mathrm{N} / \mathrm{kg} \mathrm{N}$, The factor $44 / 28$ is the conversion of $\mathrm{kg} \mathrm{N}_{2} \mathrm{O}-\mathrm{N}$ into $\mathrm{kg} \mathrm{N}_{2} \mathrm{O}, \mathrm{N}_{\text {EFFLUENT }}=$ total annual amount of nitrogen in the wastewater effluent $(\mathrm{kg} \mathrm{N} / \mathrm{yr})$, Protein $=$ annual per capita protein consumption (kg/cap/yr). Given $57.8 \mathrm{~g} / \mathrm{cap} / \mathrm{d}$ (FAO, 2013) which is $21.1 \mathrm{~kg} / \mathrm{cap} / \mathrm{yr}, \mathrm{F}_{\mathrm{NPR}}=$ fraction of nitrogen in protein, default $=0.16 \mathrm{~kg} \mathrm{~N} / \mathrm{kg}$ protein, $\mathrm{F}_{\text {NON_CON }}=$ factor for non-consumed protein added to the wastewater, 1.4 for countries with garbage disposals, $\mathrm{F}_{\text {IND_com }}$ $=$ factor for the industrial and commercial co-discharged protein into the sewer system. A factor to allow for co-discharge of industrial nitrogen into sewers, 1.25 and $\mathrm{N}_{\text {SLUDGE }}=$ nitrogen removed with sludge (default = zero) in $\mathrm{kg} \mathrm{N} / \mathrm{yr}$.

Dar es Salaam Water Supply and Sanitation Authority (DAWASA) monitors and reports only Biological Oxygen Demand (BOD) parameter from WSPs effluent of Dar es Salaam (EWURA, 2017), hence no information on nutrients monitoring was available. However, a primary main function of maturation ponds is to remove pathogens from the wastewater (Mara 1984), but since they are oxygenated throughout the day, they contribute to nutrient removal and a small degree of BOD removal.

The general balance equations for nitrogen and phosphorus in the treatment plant process is expressed by equations (15) and (16), respectively. Nitrogen and phosphorus flowing through flows (F8), (F9), (F10) and (F11), respectively.

$$
\mathrm{A}_{\mathrm{NF}}=\mathrm{A}_{\mathrm{NF} 9}+\mathrm{A}_{\mathrm{NF} 10}+\mathrm{A}_{\mathrm{NF} 11}
$$

$A_{\mathrm{PFB}}=\mathrm{A}_{\mathrm{PF} 9}+\mathrm{A}_{\mathrm{PF} 10}+\mathrm{A}_{\mathrm{PF} 11}$

where $\left(A_{N}\right)$ and $\left(A_{p}\right)$ are amount of total nitrogen and phosphorus removal from WSPs varies depending on the status and functionality of the WSPs (Tarimo, 2016). Phosphorus removal is associated with algal biomass uptake, precipitation, and sedimentation (Mara et al., 2010; von
Sperling, 2007). Nitrogen content in the effluent $A_{N F 10}$ and $A_{N F 11}$ are equal to $\mathrm{N}_{\text {EFFLUENT }}$, which was calculated using equation (16). Brandes et al. (2015) reported that only $50 \%$ of faecal sludge delivered to treatment plants is effectively treated. The effluent from the treatment plant then is distributed equally by 0.50 treated while 0.50 is not effectively treated.

Phosphorus in the effluent from treatment plant $\left(A_{P F 10} ; A_{P F 11}\right)$ is a function of the efficiency of WSP in remove of phosphorus ( $P_{-}$removal \%). The initial amount entering the treatment plants $\left(A_{\mathrm{pFg}}\right)$ and the amount of FS to be treated $\left(50 \%\right.$ of $\left.\mathrm{APF}_{\mathrm{PF}}\right)$ as presented in equation (17).

$$
A_{\text {PF10 }}=0.50 A_{P F G} \times\left(n_{P_{-} \text {removal }} \%\right)
$$

The overall nutrients removal efficiencies from anaerobic-facultative-maturation ponds given by von Sperling (2007) when assuming the WSPs work with the designing conditions, ranging from 50$65 \%$ for nitrogen and $>50 \%$ for phosphorus. This study adopted the efficiency of $\left(n_{P_{-} \text {removal }} \%\right)$ of $50 \%$ for phosphorus.

\section{RESULTS AND DISCUSSION}

\section{Characteristics of Study Population}

\section{Socio-demographic characteristics}

The average household occupancy from all the study areas was found to be 6 people. A single house consists of an average of 5 households with a total of 12 people. Respondents' age ranged from 18 to 82 years old with an average of 46.5 years old, $71.4 \%$ being women and $28.6 \%$ were men. More than a half of respondents have primary education and engaged on small businesses/entrepreneurship for economic generation activities. Level of education 
and occupation for each study area are presented in Figures 4 and 5.

\section{Water and sanitation situation}

Potable water for domestic uses was obtained from both surface and groundwater sources and water availability varied with seasons and areas. The average water consumption for uses other than bathing was found to be $46.5 \pm 27.9$ $\mathrm{L} / \mathrm{cap} / \mathrm{d}$ and for bathing was determined to be $22.4 \pm 9.1 \mathrm{~L} / \mathrm{cap} / \mathrm{d}$.

Almost all houses (99.2\%) depend on onsite sanitation systems including pit latrines and septic tanks. Manzese contains large percentage of pit latrine $(61.8 \%)$ than septic tanks while in Keko and Kipawa more households use septic tanks than pit latrines. About $76 \%$ of sanitation facilities in Manzese have already been desludged compared to Keko and Kipawa where less than $50 \%$ have been desludged.

Wastewater disposal location was found to be different in study areas. Table 2 shows percentage distribution of black water and greywater located to onsite sanitation system and used in calculating the nutrients flow in greywater.

Table 2: Wastewater disposal distribution to onsite sanitation system

\begin{tabular}{|l|c|c|}
\hline & $\begin{array}{c}\text { Black } \\
\text { water } \\
\text { only } \\
(\boldsymbol{\%})\end{array}$ & $\begin{array}{c}\text { Black water } \\
\text { and greywater } \\
\text { (from bathing) } \\
(\boldsymbol{\%})\end{array}$ \\
\hline Keko & 17.9 & 82.0 \\
\hline Kipawa & 20.6 & 79.3 \\
\hline Manzese & 53.3 & 46.7 \\
\hline
\end{tabular}

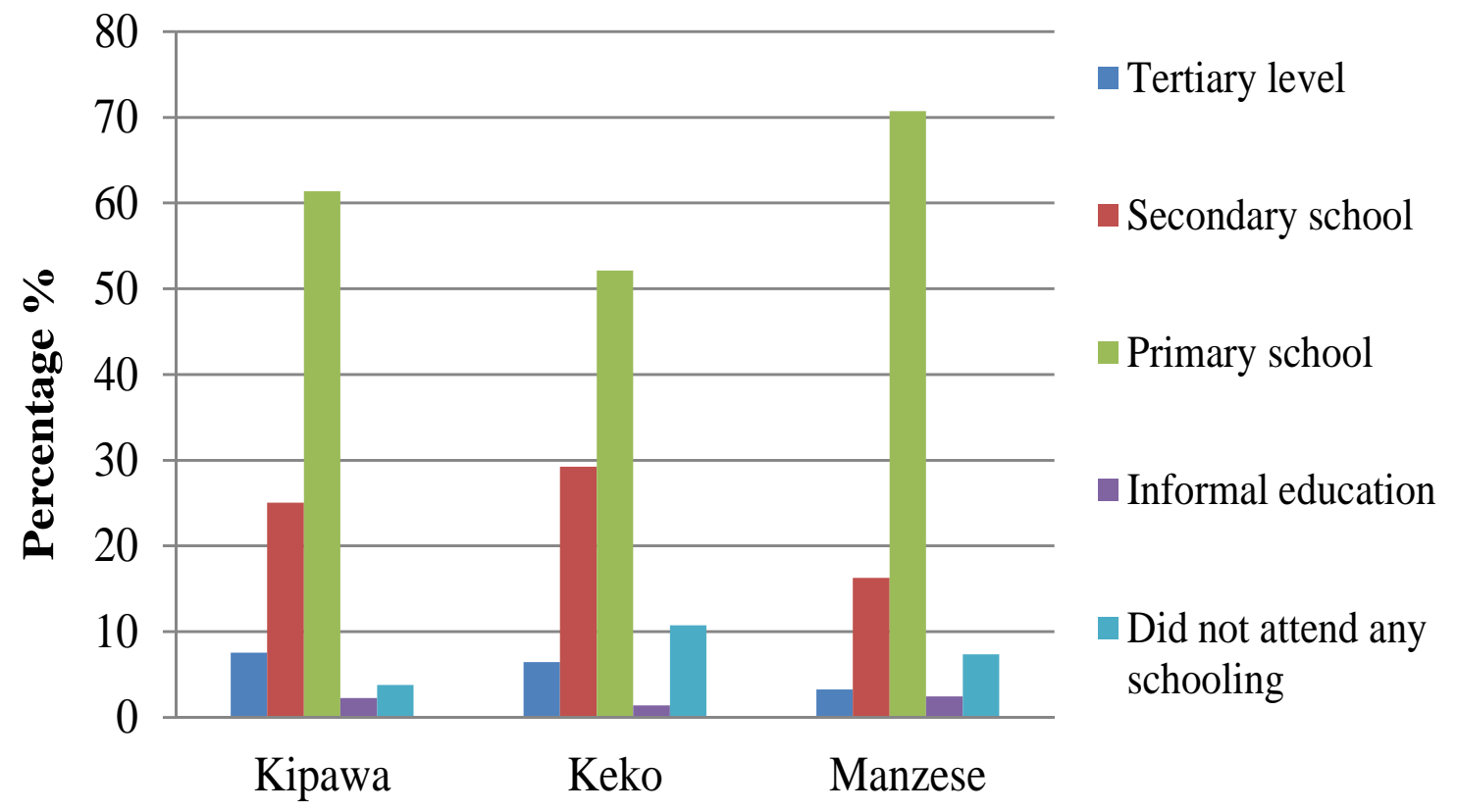

Figure 4: Percentage of respondents with education levels in each study area 


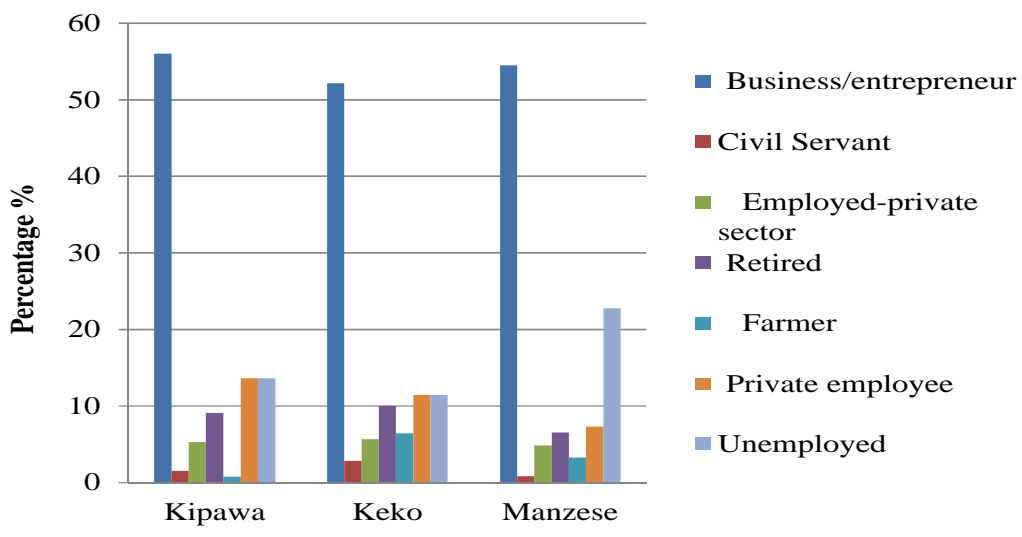

Figure 5: Percentage of respondents with occupations in each study area

\section{Materials calculated}

The mass balances for MFA was performed by STAN software using collected and calculated information. Materials flow through the system were calculated by considering combined information from three study areas as presented in Figure 6. All input, stock and output quantity of materials and nutrients estimated flowing to the system obey the law of conservation of mass. Nutrients flow were calculated and presented separately per study area for easier comparison. A summary of data inputs obtained through mathematical formulations and assumptions before mass balances are presented in Table 3 .

The households are the main contributors of greywater discharge to the environment and water bodies. On average, each year a person consumes $16.9 \mathrm{~kg}$ of water from different sources and realises more than $30 \%$ of it as greywater to the environment. Yiougo et al. (2011) analyzed similar materials in Pouytenga town in Burkina Faso. It was found that about 7000 $\mathrm{kg} / \mathrm{cap} / \mathrm{yr}$ of water is consumed and $16 \%$ of it is released as wastewater to surface water.

To reduce large amount of wastewater disposal to the environment (both greywater and faecal sludge), different options have been suggested. The separation and recycling of waste and wastewater at source can improve the situation (Meinzinger, 2010). As observed in this study, large amount of greywater from bathroom is also disposed to onsite sanitation system (Table 2), which is resulting into fast fill up of pits and therefore frequent requirement for desludging. It is suggested that separation of waste collected allows the reuse of separated greywater that comes from dishwashing and laundry activities for other activities that do not require good quality of potable water (Schaffner, 2007). However, transportation, energy and pretreatment of materials before being reused might be needed, which have cost implications.

Poor management of faecal sludge from onsite sanitation system contributes to the 
release of large amount of materials to groundwater and surface water. About 2.5 tons of faecal sludge contributed per person per year is released to the water sources without treatment. Most of toilet types found in study areas do not allow the use of vacuum tankers for desludging of pits and septic tanks contents because of inaccessibility, lack of desludging points or the use of unlined pits, which encourages the practices of unhygienic desludging like manual emptying and flood out methods of pit contents to the nearby water sources. This might be the reason for large amount of faecal sludge not being accounted for treatment.

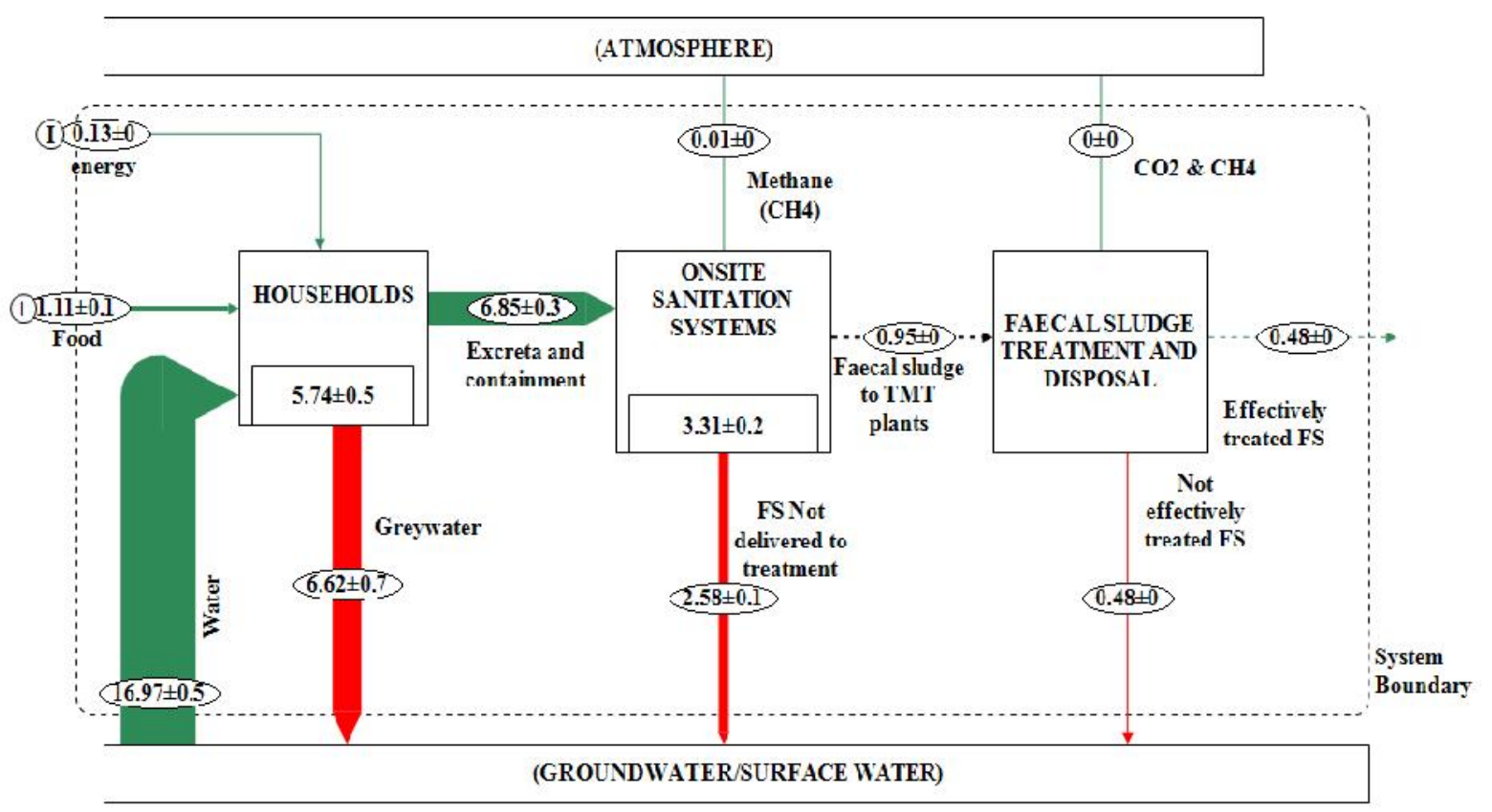

Figure 6: Mass of materials in current situation scenario of combine study areas (tons/cap/yr)

Figures 7 and 8 summarizes MFA of total nitrogen and phosphorus flows from households to treatment plants in three study areas. It was observed that in all study areas, the onsite sanitation systems (OSSs) were the main contributors and storage of materials with high amounts of nitrogen and phosphorus. This is due to the large amount of faecal sludge collected and stored within onsite sanitation system, which is about $48.3 \%$ of the generated faecal sludge (Figure 6). Through the sanitation service chain, large amount of nutrients is still emitted as a result of mismanagement of faecal sludge and wastewater. About 860 to 970 tons of nitrogen and 60 to 80 tons of phosphorus was discharged annually to the environment. The final treated FS effluent from WSPs was found to contain maximum of 143 tons/yr of nitrogen and 14 tons/yr of phosphorus from Manzese.

The amount of nitrogen disposed of from Keko area was estimated to be 0.008 tons/ca/yr, which is least amount in this study, found to be highest when compared to per capita amount in other studies. Meinzinger et al. (2009) in the town of Arba Minch in Ethiopia $(70,000$ inhabitants) found that nitrogen content of 0.0038 tons/ca/yr was disposed to the soil. In accordance with Yiougo et al. (2011), about 0.0039 tons/ca/yr of nitrogen is discharged in the soil from Pouytenga town in Burkina Faso (72,000 population), which poses groundwater pollution risks. 
Table 3: Summary of input data from mathematical formulation to mass balances by STAN software

\begin{tabular}{|c|c|c|c|c|c|}
\hline \multirow[b]{2}{*}{ Parameter } & \multicolumn{3}{|c|}{ Study area } & \multirow[b]{2}{*}{ Description/Assumptions } & \multirow[b]{2}{*}{ Reference } \\
\hline & Keko & Kipawa & Manzese & & \\
\hline Population & 79,453 & 74,180 & 70,507 & Population distribution per area & NBS (2017) \\
\hline \multicolumn{6}{|l|}{ Households Process Inflows } \\
\hline $\begin{array}{l}\text { Total Water consumption } \\
\text { (L/cap/d) }\end{array}$ & $47.87 \pm 1.96$ & $43.09 \pm 2.42$ & $48.58 \pm 2.91$ & $\begin{array}{l}\text { Average from household } \\
\text { questionnaire survey }\end{array}$ & This study \\
\hline Water for bathing (L/cap/d) & $27.24 \pm 0.27$ & $19.99 \pm 0.19$ & $21.66 \pm 0.22$ & $\begin{array}{l}\text { Average from household } \\
\text { questionnaire survey }\end{array}$ & This study \\
\hline Food $(\mathrm{kg} / \mathrm{d})$ & $8258.34 \pm 825.83$ & $7710.27 \pm 771.03$ & $7328.49 \pm 732.85$ & $\begin{array}{l}\text { Provided by FAO; uncertainty of } \\
10 \%\end{array}$ & FAO (2013) \\
\hline Energy-charcoal (tons/d) & $508.5 \pm 50.85$ & $474.75 \pm 47.48$ & $451.24 \pm 45.12$ & Charcoal consumption & $\begin{array}{l}\text { Msuya et al. (2011); Meinzinger } \\
(2010) \text {. }\end{array}$ \\
\hline \multicolumn{6}{|l|}{ Process Outflow } \\
\hline \multirow[b]{2}{*}{ Excreta-wet weight (g/cap/d) } & \multicolumn{3}{|c|}{$520 \pm 173.2$} & Faeces generation & \multirow{2}{*}{$\begin{array}{l}\text { Chaggu (2004); Afolabi and Sohail } \\
(2017)\end{array}$} \\
\hline & \multicolumn{3}{|c|}{$1500 \pm 722.5$} & Urine generation & \\
\hline Containment inflow (kg/cap/d) & $25.96 \pm 0.92$ & $19.81 \pm 0.59$ & $21.22 \pm 0.69$ & $\begin{array}{l}\text { Average amount of water for bathing } \\
\text { in each area }\end{array}$ & This study \\
\hline Greywater (kg/cap/d) & $9.94 \pm 0.55$ & $12.51 \pm 1.22$ & $15.215 \pm 1.49$ & $\begin{array}{l}75 \% \text { of water consumption minus } \\
\text { water from bathroom }\end{array}$ & This study \\
\hline \multicolumn{6}{|c|}{ Onsite sanitation system Process Inflows } \\
\hline Excreta (g/cap/d) & \multicolumn{3}{|c|}{$1500 \pm 895.7$} & Faeces and urine generated & This study \\
\hline Greywater (kg/cap/d) & $8.15 \pm 0.45$ & $9.88 \pm 0.96$ & $7.15 \pm 0.70$ & $\begin{array}{l}82.0 \% \text { (Keko), } 79.34 \% \text { (Kipawa) and } \\
\text { 46.74\% (Manzese) of water from } \\
\text { bathroom }\end{array}$ & This study \\
\hline \multicolumn{6}{|l|}{ Process Outflow } \\
\hline $\begin{array}{l}\text { Faecal sludge to treatment } \\
\text { plants }(\mathrm{kg} / \mathrm{cap} / \mathrm{yr})\end{array}$ & $1.12 \pm 0.16$ & $1.19 \pm 0.19$ & $1.77 \pm 0.33$ & $\begin{array}{l}27 \% \text { of FS Emptied (13.93\% of FS } \\
\text { generated) }\end{array}$ & This study \\
\hline $\begin{array}{l}\text { Faecal sludge NOT to } \\
\text { treatment plants }(\mathrm{kg} / \mathrm{yr})\end{array}$ & $3.03 \pm 0.42$ & $3.24 \pm 0.53$ & $4.79 \pm 0.88$ & $\begin{array}{l}73 \% \text { of FS Emptied ( } 37.67 \% \text { of FS } \\
\text { generated) }\end{array}$ & This study \\
\hline $\begin{array}{l}\text { Gases generated from septic } \\
(\mathrm{kg} \mathrm{CH} / \mathrm{yr})\end{array}$ & $141,637.68$ & $105,189.09$ & $37,135.68$ & $\begin{array}{l}\text { Methane emission from septic tanks; } \\
\text { uncertainty of } 10 \%\end{array}$ & \multirow[b]{2}{*}{$\begin{array}{l}\text { Orner and Mihelcic, (2018); IPCC } \\
(2006)\end{array}$} \\
\hline $\begin{array}{l}\text { Gases generated from pit } \\
\text { latrine }\left(\mathrm{kg} \mathrm{CH}_{4} / \mathrm{yr}\right)\end{array}$ & $189,279.45$ & $265,076.52$ & $343,933.57$ & $\begin{array}{l}\text { Methane emission from pit latrines: } \\
\text { uncertainty of } 10 \%\end{array}$ & \\
\hline
\end{tabular}

Tanzania Journal of Engineering and Technology (Tanz. J. Engrg. Technol.), Vol. 38 (No. 1), June 2019 


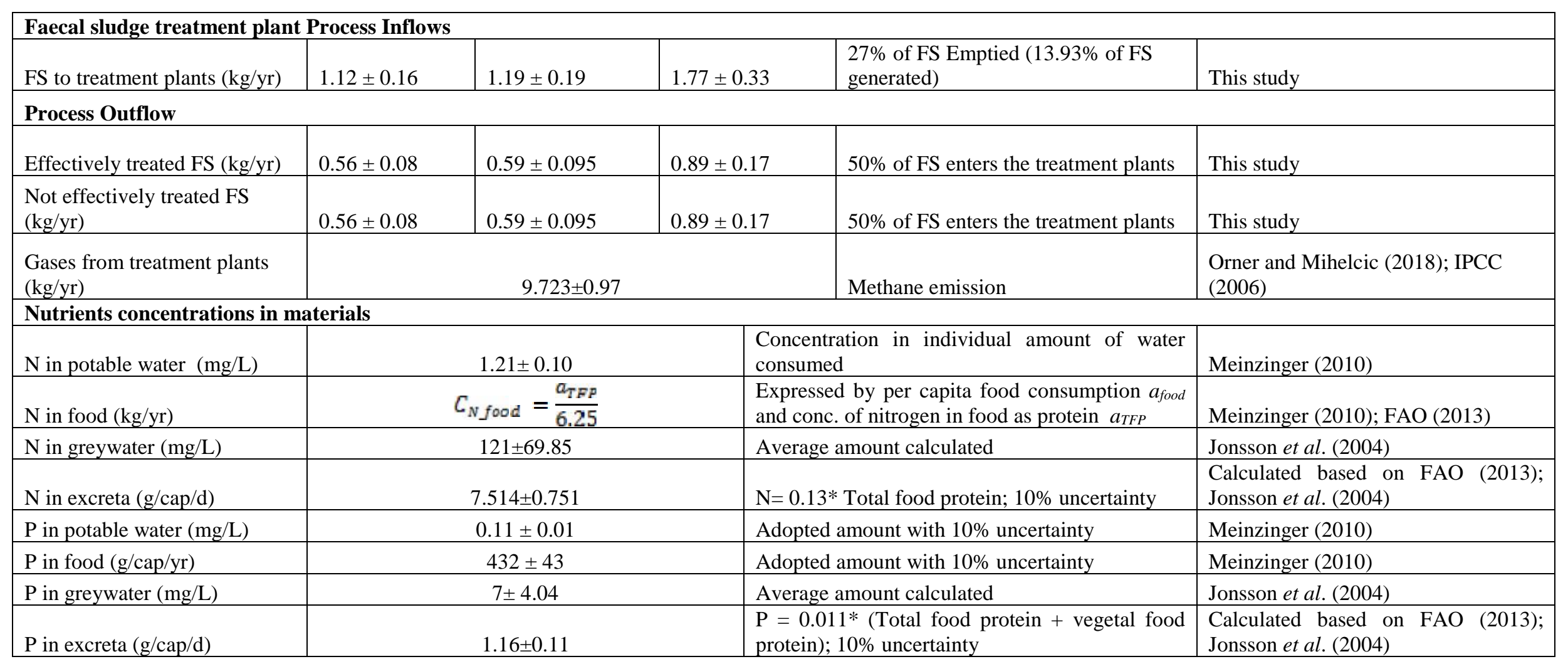




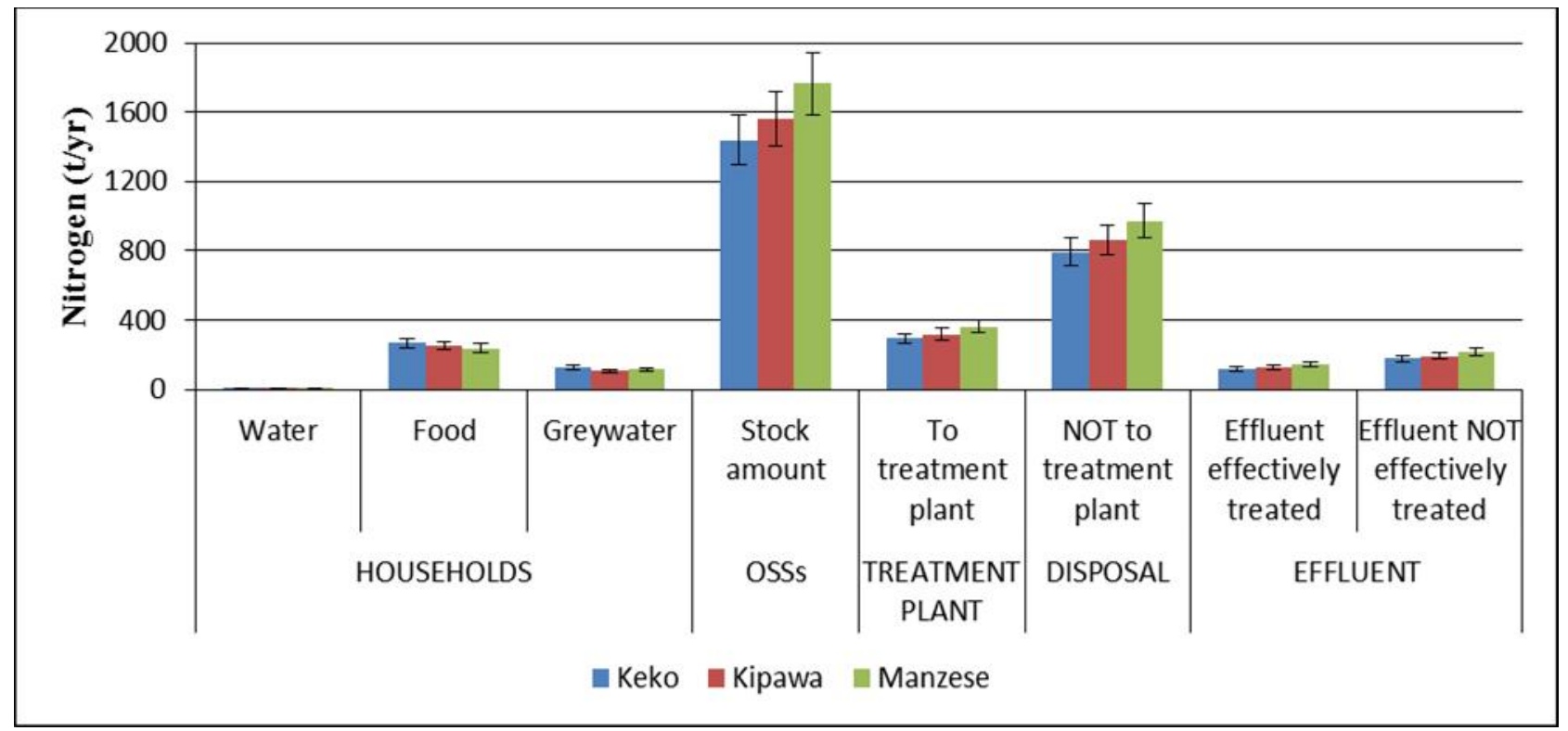

OSSs = Onsite Sanitation Systems

Figure 7: Amount of Nitrogen flow with materials along sanitation service chain processes (t/yr)

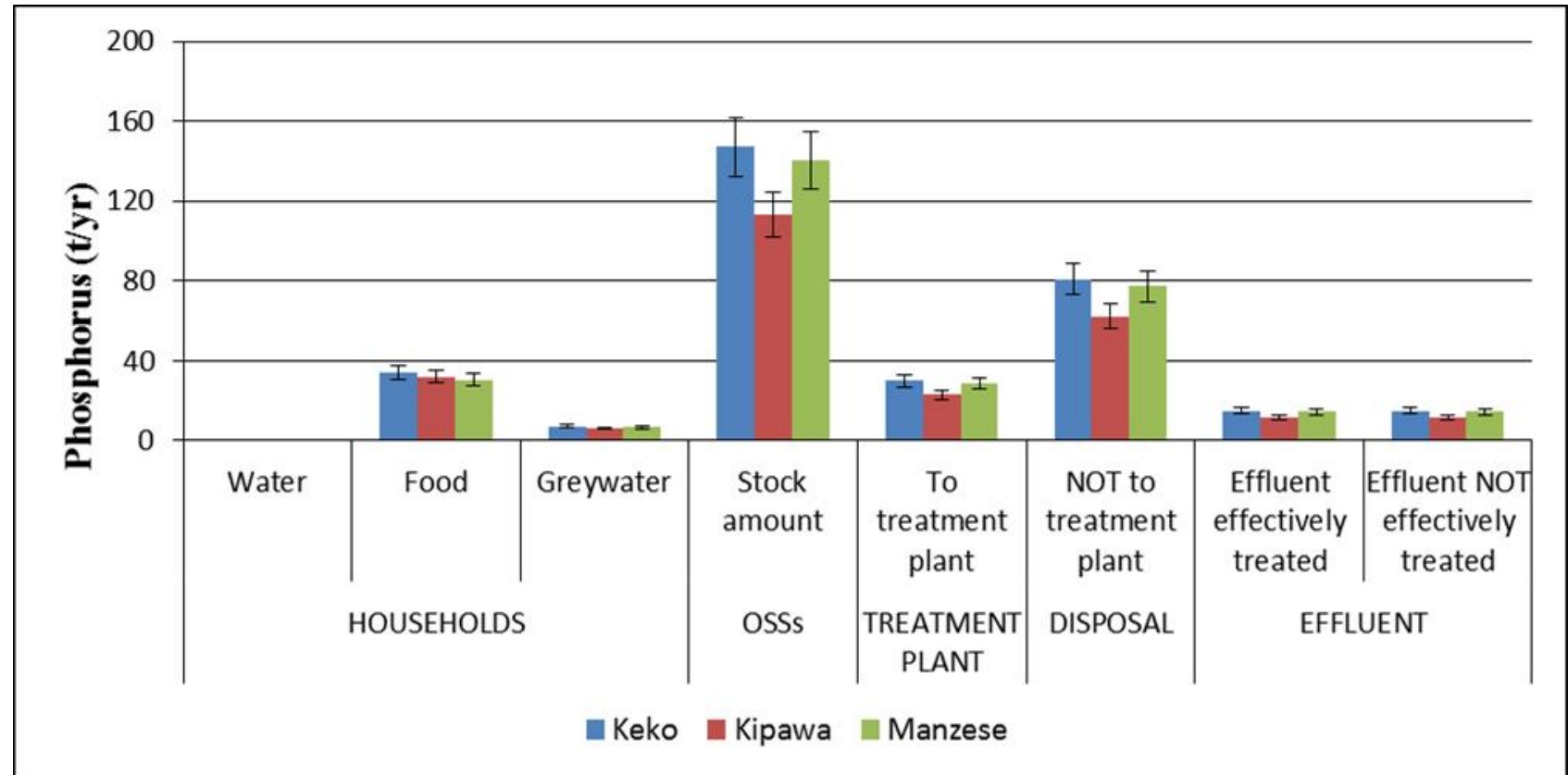

OSSs = Onsite Sanitation Systems

Figure 8: Amount of Phosphorus flow with materials along sanitation service chain processes (tons/yr)

Different systems are available that allow the recovery of nutrients from wastewater flows that suit the specific conditions. These include the introduction of composting or urine diversion systems to allow the use of collected materials for agriculture. In accordance with
Meinzinger (2010), application of these systems may recover about $17 \%$ of nitrogen and $25 \%$ of phosphorus generated in Arba Minch City of Ethiopia. 


\section{Limitation of Results}

Material flow analysis method was used to quantify both materials and nutrients flowing to the specified system. By focusing on material analysis at a community level, the use of MFA in this study encountered some limitations include;

- The lack of data for validation of output of input data when using STAN software at this stage of the study.

- The MFA does not consider social-cultural and health consideration aspects to a community as consumers of products to be produced. These factors might limit the implementation of faecal sludge recovery and reuse for agriculture and energy.

- MFA method is static because it uses oneyear temporal boundary for evaluation. To cover several years for comparison, large data set is required.

\section{CONCLUSIONS}

From the results of this work it can be concluded that water was the main material imported to the system whereby a person consumes on average 17.0 tons/cap/yr of water, which generates 6.6 tons/cap/yr of greywater disposed to water bodies and an open environment without treatment. Onsite sanitation systems were the major pollutants of the environment and water bodies contributing more than 2 tons/cap/yr of faecal sludge, which was disposed of through seepage of unlined systems to the soil or illegally disposed of in the environment. About 0.48 tons/cap/yr of faecal sludge is disposed of from treatment plants without effective treatment.

Along sanitation service chain, nutrients are not captured for utilization. From treatment plants, a small quantity of nutrients remained are further disposed of with effluents to water bodies, which in accumulation may impact the environment and ecology of the water bodies.

Lack of proper faecal sludge and wastewater management in unplanned settlements encourages people to practice illegal faecal sludge disposal to the environment. This was evident from the large amount of nutrients discharged to the environment without treatment, which was $37.7 \%$ of the faecal sludge that emptied from onsite sanitation systems. To remove nutrients from the water stream, municipalities and responsible authorities need to put resource recovery in sanitation plans from the initial stage. Capacity building, incentives and education on resource recovery to communities are need, important for the proposed projects to sustain.

\section{Acknowledgement}

Sincere thanks are extended to the Swedish International Development Cooperation Agency (SIDA) for funding the SUSTAIN project in the Department of Water Resources at University of Dar es Salaam, Tanzania. Special thanks to Lund University Centre for Sustainability Studies (LUCSUS) at Lund University, Sweden for co-supervising the project and their material support.

\section{REFERENCES}

Afolabi O.O.D. and Sohail M. (2017). Microwaving human faecal sludge as a viable sanitation technology option for treatment and value recovery: A critical review. Journal of Environmental Management 187: 401-415. http://dx.doi.org/10.1016/j.jenvman.2016.10.067

Allesch A. and Brunner P.H. (2015). Material Flow Analysis as a decision: A literature review. Wiley Online Library, 19(5): 753764. https://doi.org/10.1111/jiec.12354

Andriani D., Wresta A., Saepudin A. and Prawara B. (2015). A review of recycling of human excreta to energy through biogas generation: Indonesia case. Energy Procedia, 68: 219-225. https://doi.org/10.1016/j.egypro.2015.03.25 0

Atwijukye O., Kulabako R., Niwagaba C. and Sugden S. (2018). Low cost faecal sludge dewatering and carbonisation for production of fuel briquettes. 41st WEDC International Conference, Egerton University, Nakuru, 
Kenya. Transformation Towards Sustainable and Resilient WASH services, (Sept.), 1-7.

Brandes K., Schoebitz L., Kimwaga R., and Strande L. (2015). Shit Flow Diagram report for Dar es Salaam, SFD Promotion Initiative Dar es Salaam, Tanzania, Final Report.

Cencic O. and Rechberger H. (2008). Material Flow Analysis with software STAN. Environ. Eng. Management, 18(1): 3-7.

Chaggu E.J. (2004). Sustainable environmental protection using modified pit latrines. $\mathrm{PhD}$ Thesis, Department of Environmental Technology, Wageningen University, The Netherlands.

de Langen M. (2007). Engineering Economics: Hypothesis Testing. UNESCO-IHE Institute for Water Education, Delft, The Netherlands.

Diener S., Semiyaga S., Niwagaba C.B., Muspratt A.M., Gning J.B., Mbéguéré M., Ennin J.E., Zurbrugg C. and Strande L. (2014). A value proposition: Resource recovery from faecal sludge- Can it be the driver for improved sanitation? Resources, Conservation and Recycling, 88: 32-38. https://doi.org/10.1016/j.resconrec.2014.04. 005

Do-thu N., Morel A., Nguyen-viet H. and Pham-duc P. (2011). Assessing nutrient fluxes in a Vietnamese rural area despite limited and highly uncertain data. Resources, Conservation \& Recycling, 55(9-10): 849-856. https://doi.org/10.1016/j.resconrec.2011.04. 008

Dongus S., Nyika D., Kannady K. and Mtasiwa D. (2009). Urban agriculture and Anopheles habitats in Dar es Salaam, Tanzania. Geospatial Health, 3(2): 189-210. https://doi.org/10.4081/gh.2009.220

Drechsel P., Cofie O., Fink M., Danso G., Zakari F.M. and Vasquez R. (2004). Closing the rural-urban nutrient cycle: Options for municipal waste composting in Ghana. Final scientific report submitted to IDRC (Project 100376). IWMI, Ghana.

EWURA (2014). Water and wastewater quality monitoring guidelines for water utilities. Dar es Salaam, United Republic of Tanzania.
Rome, Italy. Available online at http://www.fao.org/statistics/en/Tanzania. Retrieved on 30th may 2019.

Gold M., Cunningham M., Bleuler M., Arnheiter R., Schönborn A., Niwagaba C., and Strande L. (2018). Operating parameters for three resource recovery options from slow-pyrolysis of faecal sludge. Journal of Water, Sanitation and Hygiene for Development, 8(4): 707-717. https://doi.org/10.2166/washdev.2018.009

Gold M., Niang S., Niwagaba C.B., Eder G., Muspratt A.M., Diop P.S. and Strande L. (2014). Results from FaME (Faecal Management Enterprises ) - can dried faecal sludge fuel the sanitation service chain? 37th WEDC International Conference, Hanoi, Vietnam, 2014 Sustainable Water and sanitation Services for All in Fast Changing World, 1-6.

IPCC (2006). Wastewater treatment and discharge. In D. Michiel \& W. Irving (Eds.), IPCC Guidelines for National Greenhouse Gas Inventories (5: Waste, p. 28).

Jenkins M.W., Cumming O. and Cairncross S. (2015). Pit latrine emptying behavior and demand for sanitation services in Dar Es Salaam, Tanzania. Int. J. Environ. Res. Public Health, 12: 2588-2611; doi:10.3390/ijerph120302588

Jonsson H., Stinzing A.R., Vinneras B. and Salomon E. (2004). Guidelines on the use of urine and faeces in crop production. EcoSanRes Publication Series 2: 1-35.

Kasala S.E., Burra M.M. and Mwankenja T.S. (2016). Access to improved sanitation in informal settlements: The case of Dar es Salaam city, Tanzania. Current Urban Studies, $\quad 4$ : 23-35. http://dx.doi.org/10.4236/cus.2016.41003

Katukiza, A.Y. (2013). Sanitation in unsewered urban poor areas: Technology selection, quantitative microbial risk assessment and greywater treatment. Available online at edepot.wur.nl/283065. Retrieved on 30th May 2019.

Kayombo M.C. and Mayo A.W. (2018). Assessment of microbial quality of vegetables irrigated with polluted waters in Dar es Salaam City, Tanzania. 
Environmental and Ecology Research, 6(4): 229-239.

https://doi.org/10.13189/eer.2018.060403

Kwapinski W., Byrne C.M.P., Kryachko E., Wolfram P., Adley C., Leahy J.J., Novotny E.H. and Hayes M.H.B. (2010). Biochar from biomass and waste. Waste Biomass Valor, 1 : 177-189. https://doi.org/10.1007/s12649-010-9024-8

Lalander C., Diener S., Magri M.E., Zurbrügg C., Lindström A. and Vinnerås B. (2013). Faecal sludge management with the larvae of the black soldier fly (Hermetia illucens) From a hygiene aspect. Science of the Total Environment, 458-460: 312-318. https://doi.org/10.1016/j.scitotenv.2013.04.0 33

Leonard S., Mwegoha W. and Kihampa C. (2012). Heavy metals pollution and urban agriculture in Msimbazi River valley: Health risks and public awareness. International Journal of Plant, Animal and Environmental Sciences, 2(2): 107-118.

Liu X., Li Z., Zhang Y., Feng R. and Mahmood I.B. (2014). Characterization of human manure-derived biochar and energy-balance analysis of slow pyrolysis process. Waste Management, 34(9): 1619-1626. https://doi.org/10.1016/j.wasman.2014.05.0 27

Malale M.P. and Munishi S. (2018). Surface water quality in the peri-urban areas in Dar es Salaam, Tanzania: The case of Ng'ombe River. Tanzania Journal of Engineering and Technology, 37(1): 19-32.

Mara D.D. (1984). The design of ventilated improved pit latrines. TAG Technical Note, (13): 83.

Mara D.D, Lane J., Scott B. and Trouba D. (2010). Sanitation and Health. PLoS Med, 7(11): https://doi.org/10.1371/journal.pmed.10003 63

Marwa L.I. (2017). Development of potential predictors for faecal sludge characterization on a community scale: The case study of Mlalakua community, Dar es Salaam. MSc. Dissertation, University of Dar es Salaam, Tanzania.

Meinzinger F. (2010). Resource efficiency of urban sanitation systems: A comparative assessment using material and energy flow analysis. Technischen Universität HamburgHarburg, Germany.

Montangero A. (2006). Material Flow Analysis for environmental sanitation planning in developing countries. PhD Thesis, LeopoldFranzens-University Innsbruck, Austria.

Montangero A. (2009). Material flow analysis as a tool for sustainable sanitation planning in developing countries: Case study of Arba Minch, Ethiopia. Water Sci Technol., 59(10): 1911-1920. doi: 10.2166/wst.2009.189.

Montangero A. and Belevi H. (2007). Assessing nutrient flows in septic tanks by eliciting expert judgement: A promising method in the context of developing countries. 41: 1052-1064. https://doi.org/10.1016/j.watres.2006.10.036

Montangero A. and Belevi H. (2008). An approach to optimise nutrient management in environmental sanitation systems despite limited data. 88: 1538-1551. https://doi.org/10.1016/j.jenvman.2007.07.0 33

Montangero A., Cau L.N., Anh N.V., Tuan V.D., Nga P.T. and Belevi H. (2007). Optimising water and phosphorus management in the urban environmental sanitation system of Hanoi, Vietnam. Science of the Total Environment, 384(1-3): $55-66$.

https://doi.org/10.1016/j.scitotenv.2007.05.0 32

Msuya N., Masanja E. and Temu A.K. (2011). Environmental burden of charcoal production and use in Dar es Salaam, Tanzania. Journal of Environmental Protection, $\quad 2$ 1364-1369 doi:10.4236/jep.2011.210158

Munamati M., Nhapi I. and Misi S. (2016). Exploring the determinants of sanitation success in Sub-Saharan Africa. Water Research, 103: 435-443. https://doi.org/10.1016/j.watres.2016.07.030

Mwakaboko A.S., Lugwisha E.H.J. and Kayogolo C.W. (2014). The performance of the selected waste stabilization ponds in Dar es Salaam, Tanzania in removing heavy 
metals. International Journal of Science, Environment and Technology, 3(6): 20242037.

National Bureau of Statistics (NBS) (2017). Basic demographic and socio-economic profile. 2012 Population and Housing Census. Dar es Salaam: National Bureau of Statistics (NBS), Ministry of Finance, Dar es Salaam, Tanzania. Available online at http://tanzania.countrystat.org/fileadmin/use r_upload/countrystat_fenix/congo/docs/2012 Tanzania Population and Housing CensusBasic Demographic and Socio-Economic Profile.pdf. Retrieved on 15th June 2019.

Niwagaba C., Mbeguere M. and Strande L. (2014). Faecal sludge quantification, characterization and treatment objectives. In Strande L., Ronteltap M. and Brdjanovic D. (Eds.), Faecal sludge management: System approach for implementation and operation. IWA Publishing.

Niwagaba C., Nalubega M., Vinnerås B., Sundberg C. and Jönsson H. (2009). Benchscale composting of source-separated human faeces for sanitation. Waste Management, 29(2): $585-589$. https://doi.org/10.1016/j.wasman.2008.06.0 22

Nyer B. (2012). Fuel briquette materials assessment. TechnoServe Guatemala, University of Colorado, USA.

Orner K.O. and Mihelcic J.R. (2018). A review of sanitation technologies to achieve multiple sustainable development goals that promote resource recovery. Journal of Environmental Science: Water Research \& Technology, 4: 16-32.

https://doi.org/10.1039/C7EW00195A

Sawio C.J. (1994). Urban agriculture and the sustainable Dar es Salaam project Cities Feeding People Series.

Schaffner, M. (2007). Applying a material flow analysis model to assess river water pollution and mitigation potentials: A case study in the Thachin River basin, Central
Thailand. PhD Thesis, Universität Bern, Switzerland.

Schoebitz L., Niwagaba C., Francis O., Bischoff F. and Strande L. (2014). FAQ: Faecal Sludge Quantification and Characterization - Kampala. Sandec News, 15(January), 12-13.

Strauss M. and Montangero A. (2002). Faecal sludge management review of practices. In: Problems and initiatives. London and Duebendorf: DFID Project R8056, Capacity Building for Effective Decentralised Wastewater Management. Swiss Federal Institute of Aquatic Science (EAWAG), Department of Water and Sanitation in Developing Countries (SANDEC).

Tarimo I.A. (2016). Removal of wastes and reuse of treated water from Maturation Waste Stabilization Ponds (MWSPs). International Journal for Innovation Education and Research, 4(11): 31-50.

UN-Habitat (2009). Global report on human settlements: Planning sustainable cities. Retrieved from Earthscan website: www.unhabitat.org

Vijayan G., Saravanane R. and Sundararajan T. (2017). Carbon footprint analyses of wastewater treatment systems in Puducherry. Computational Water, Energy, and Environmental Engi- Neering, 6: 281303.

https://doi.org/10.4236/cweee.2017.63019

von Sperling M. (2007). Biological wastewater treatment. Waste Stabilisation Ponds (3rd ed.). London: IWA Publishing.

Yiougo L.S.A., Koanda H., Wethe J., Luthi C., Yapo O. and Dapola E.D. (2011). The method of material flow analysis: A tool for selecting sustainable sanitation technology options: The case of Pouytenga (Burkina Faso). Water Resources Management VI(145): 671-680. 